\title{
PENGARUH KUALITAS PRODUK DAN CITRA MEREK TERHADAP KEPUASAN PELANGGAN DAN DAMPAKNYA TERHADAP KOMUNIKASI WORD OF MOUTH
}

\author{
Putu Mertayasa ${ }^{1}$ \\ I Gusti Ayu Ketut Giantari²
}

${ }^{1,2}$ Fakultas Ekonomi dan Bisnis Universitas Udayana (Unud), Bali, Indonesia

Email: putumertayasa99@gmail.com

\begin{abstract}
The Effect of Product Quality and Brand Image on Customer Satisfaction and Its Impact on Word of Mouth Communication. The purpose of this study was to explain the effect of product quality and brand image on IndiHome customer satisfaction in Denpasar City, and to explain the effect of product quality, brand image and customer satisfaction on IndiHome customers' word of mouth communication in Denpasar City. The population in this study were all IndiHome customers in Denpasar City. The sampling technique used is purposive sampling method. The number of samples used in this study were 100 respondents. The data analysis technique used in this study is path analysis. The results showed that product quality and brand image had a positive and significant effect on IndiHome customer satisfaction in Denpasar City, and product quality, brand image and customer satisfaction had a positive and significant effect on IndiHome customers 'word of mouth communication in Denpasar City.
\end{abstract}

Keywords: product quality, brand image, customer satisfaction, WOM communication

\begin{abstract}
Abstrak: Pengaruh Kualitas Produk Dan Citra Merek Terhadap Kepuasan Pelanggan Dan Dampaknya Terhadap Komunikasi Word Of Mouth. Tujuan penelitian ini adalah untuk menjelaskan pengaruh kualitas produk dan citra merek terhadap kepuasan pelanggan IndiHome di Kota Denpasar, serta untuk menjelaskan pengaruh kualitas produk, citra merek dan kepuasan pelanggan terhadap komunikasi word of mouth pelanggan IndiHome di Kota Denpasar. Populasi dalam penelitian ini adalah seluruh pelanggan IndiHome di Kota Denpasar. Teknik penentuan sampel yang digunakan adalah metode purposive sampling. Jumlah sampel yang digunakan dalam peenelitian ini adalah sebanyak 100 responden. Teknik analisis data yang digunakan dalam penelitian ini adalah analisis jalur. Hasil penelitian menunjukkan bahwa kualitas produk dan citra merek berpengaruh positif dan signifikan terhadap kepuasan pelanggan IndiHome di Kota Denpasar, serta kualitas produk, citra merek dan kepuasan pelanggan berpengaruh positif dan signifikan terhadap komunikasi word of mouth pelanggan IndiHome di Kota Denpasar.
\end{abstract}

Kata Kunci: kualitas produk, citra merek, kepuasan pelanggan, komunikasi WOM 


\section{PENDAHULUAN}

Kebutuhan teknologi informasi dan adalah 132,7 juta user atau sekitar 51,5\% dari komunikasi yang semakin berkembang, total jumlah penduduk Indonesia sebesar 256,2 menyebabkan jumlah pengguna internet di juta. Hasil survei yang dipresentasikan oleh Indonesia semakin meningkat setiap Tahunnya. APJII itu mencatat bahwa jumlah pengguna Hal ini didukung oleh hasil survey data internet di Bali \& Nusa mencapai 6.148.796 pengguna internet di Indonesia menurut Asosiasi orang atau 4,7 persen dari keseluruhan user Penyelenggara Jaringan Internet Indonesia di Indonesia. Jumlah pengguna internet yang (APJII) yang terangkum dalam Gambar 1. semakin meningkat ini menunjukkan bahwa

Survei yang dilakukan oleh Asosiasi teknologi informasi dan komunikasi semakin Penyelenggara Jasa Internet Indonesia (APJII) berkembang.

dalam Gambar 1 mengungkap bahwa lebih

Perkembangan teknologi informasi dari setengah penduduk Indonesia kini telah dan komunikasi merupakan peluang bisnis terhubung ke internet. Survei yang dilakukan yang potensial bagi perusahaan penyedia jasa sepanjang 2016 itu menemukan bahwa jumlah telekomunikasi. Teknologi telekomunikasi di era

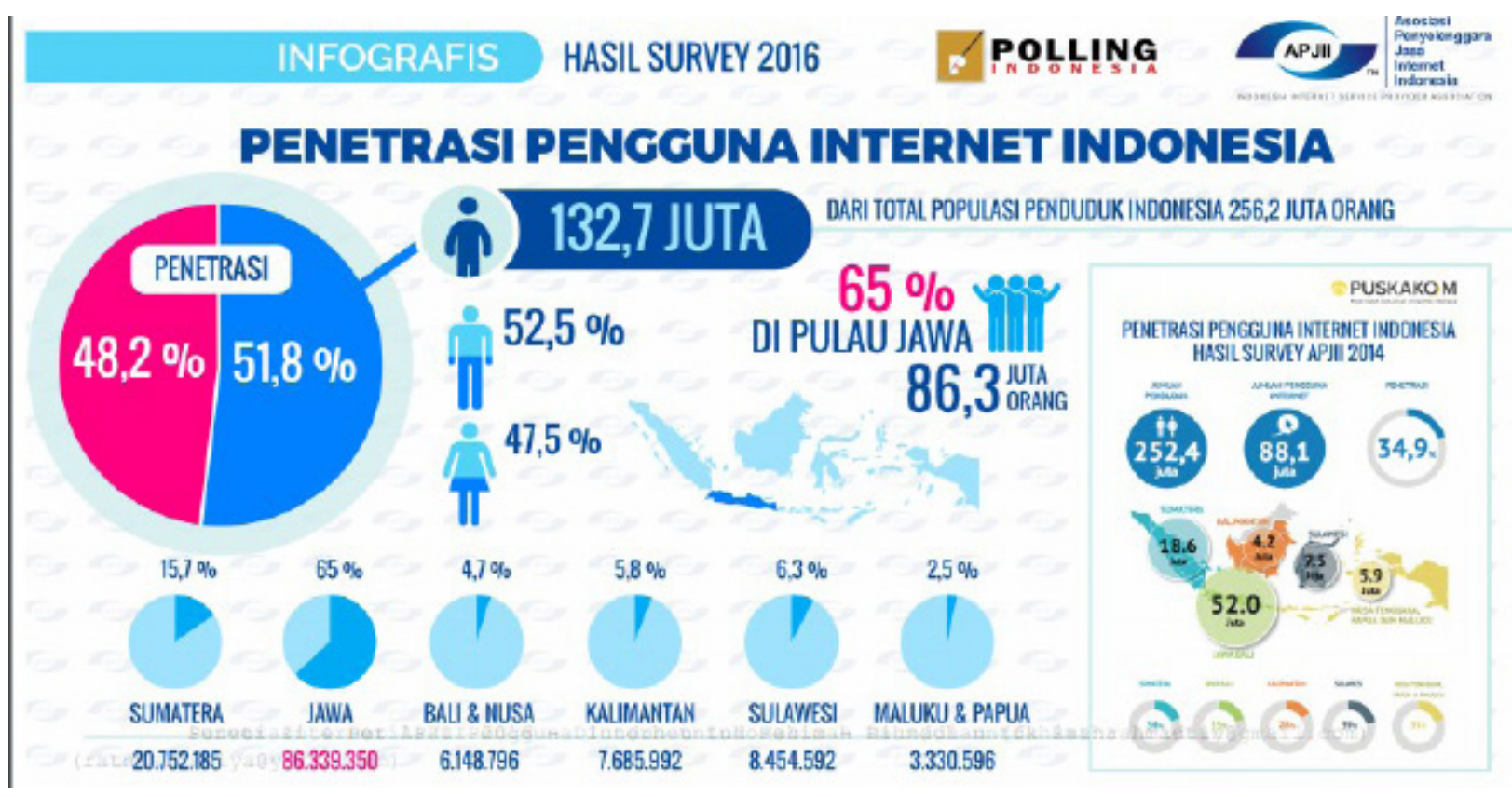

Gambar 1.

Hasil Survey Data Pengguna Internet di Indonesia

Sumber : Asosiasi Penyelenggara Jasa Internet Indonesia 
digitalisasi semakin mendapat tempat sebagai kecepatan akses yang dipercaya cukup salah satu sektor bisnis yang berkembang pesat. membuat masyarakat Indonesia tertarik Hal tersebut menjadi pendorong sekaligus untuk menggunakannya. Masalah yang tantangan seluruh perusahaan teknologi dihadapi Telkom sekarang ini adalah semakin komunikasi di dunia untuk menciptakan berkembangnya penyedia jasa layanan internet produk yang dapat memenuhi kebutuhan pasar. yang semakin banyak dengan menawarkan Tantangan ini juga didukung oleh keberadaan harga-harga yang kompetitif dengan perusahaan sejenis yang menawarkan produk berbagai produk yang bervariatif, sehingga dengan karakteristik yang hampir sama. Telkom dituntut untuk secara terus menerus Persaingan berdampak pada penciptaan produk meningkatkan kualitas produk IndiHome untuk baru sebagai tindakan penguasaan pasar dan meningkatkan kepuasan pelanggan (Hakim, mempertahankan eksistensi perusahaan. 2015). Dalam menjalankan aktivitas bisnisnya, Perusahaan membuat variasi penawaran produk Telkom khususnya pada program IndiHome ini untuk tujuan yang menguntungkan. Perusahaan banyak mendapat komplain dari pelanggan. dapat menarik konsumen dengan memberikan Yayasan Lembaga Konsumen Indonesia penawaran produk berkualitas sebagai pilihan (YLKI) dalam Media Okezone.com mengaku bagi konsumen (Putra, dkk. 2017) menerima banyak keluhan terkait layanan PT. Telekomunikasi Indonesia, Tbk IndiHome yang dianggap tidak transparan. (Telkom) merupakan salah satu perusahaan Kepala Bidang Yayasan Lembaga Konsumen penyedia jasa telekomunikasi yang Indonesia (YLKI) mengatakan bahwa konsep memanfaatkan peluang tersebut. Pemenuhan triple-play milik IndiHome masih banyak akan kebutuhan teknologi internet dijawab membuat konsumen kebingungan. Indihome dengan dikembangkannya berbagai produk Triple Play yang merupakan salah satu produk berbasis pemenuhan kebutuhan terhadap akses dari PT. Telkom Indonesia Tbk Witel Denpasar, internet, salah satu produknya adalah IndiHome. berhasil menarik pelanggan untuk memakai Produk IndiHome memberikan produk Indihome Triple Play tersebut. Berbagai kemudahan dalam mengakses internet dengan keunggulan produk yang ditawarkan tentunya 
tidak terlepas dari berbagai kelemahan yang menyertai setiap produk. Harapan pelanggan mengenai produk dan pelayanan Indihome Triple Play tentunya mengharapkan yang terbaik (Armanto, 2018). Namun pada nyatanya, masih banyak keluhan atau komplain yang diterima oleh PT. Telkom Indonesia Tbk Witel Denpasar pada Bulan Maret 2018 yang secara rinci disajikan dalam Tabel 1.

Data dalam Tabel 1 menunjukkan bahwa jumlah kasus gangguan Indihome Triple Play selama bulan Maret 2018 mencapai 51 pengaduan gangguan di Kota Denpasar. Responden menyatakan bahwa sering ini disebabkan karena adanya ketidaksesuaian mengadukan komplainnya terkait layanan harapan konsumen terhadap layanan Telkom Indihome Triple Play di PT. Telkom Indonesia Indihome. Oleh karena itu, PT. Telekomunikasi Tbk Witel Denpasar. Salah satu responden Indonesia, tbk dituntut untuk selalu melakukan mengatakan bahwa paket internet yang perubahan dan perbaikan kearah yang lebih

Tabel 1.

Jumlah Komplain Pelanggan Indihome Triple Play di Kota Denpasar pada Bulan Maret 2018

\begin{tabular}{lc}
\hline \multicolumn{1}{c}{ Jenis Komplain } & Jumlah Komplain \\
\hline $\begin{array}{l}\text { Gangguan Fiber Optik (gangguan channel tv kabel, internet, dan } \\
\text { telpon rumah). }\end{array}$ & 14 \\
\hline $\begin{array}{l}\text { Kualitas tv kabel yang buruk atau chanel tidak perbarui, dan } \\
\text { teleponon yang tiba-tiba sering terputus }\end{array}$ & 9 \\
\hline Internet yang melambat seiring pemakaian & 17 \\
\hline $\begin{array}{l}\text { Koneksi internet yang terputus secara tiba-tiba terkadang } \\
\text { jaringan tidak memadai }\end{array}$ & \\
\hline
\end{tabular}

Sumber : PT. Telkom Indonesia Tbk Witel Denpasar Bulan Maret, 2018 
baik lagi untuk setiap aspeknya. Salah satu cara untuk mengetahui performansi perusahaan saat ini adalah melalui informasi dari pelanggan mengenai kepuasan terhadap layanan yang telah diberikan (Sari, 2014).

Kualitas memiliki hubungan yang erat dengan kepuasan pelanggan. Kualitas memberikan suatu dorongan kepada pelanggan untuk menjalin ikatan hubungan yang kuat dengan perusahaan. Dalam jangka panjang, ikatan seperti ini memungkinkan perusahaan untuk memahami dengan seksama harapan pelanggan serta kebutuhan mereka. Dengan demikian, perusahaan dapat meningkatkan kepuasan pelanggan di mana perusahaan memaksimumkan pengalaman pelanggan yang menyenangkan dan meminimumkan pengalaman pelanggan yang kurang menyenangkan (Zubair dan Triyonowati, 2015). Hasil penelitian yang ditemukan oleh Putra, dkk (2017), Puspita (2015), Wahyuni (2017), Wedarini (2013), Damayanti (2015) dan Setyawan (2015) menemukan bahwa kualitas produk berpengaruh positif dan signifikan terhadap kepuasan konsumen.

Peningkatan kualitas produk sangat perlu dilakukan untuk perusahaan. Jika perusahaan dapat meningkatkan kualitas produknya, maka perusahaan tersebut akan dapat tetap memuaskan para konsumen dan konsumen akan merekomendasikan dan menceritakan apa yang mereka rasakan kepada orang lain. Hal ini berarti, dengan kualitas produk yang baik maka konsumen akan merasa puas dan akan sangat mendukung terlaksananya pemasaran word of mouth positif terhadap suatu produk (Sari, 2014). Penelitian yang dilakukan oleh Rambe, dkk (2017), Zhang, et al. (2010), Pranastiti (2012), dan Satmoko, dkk. (2015) memperoleh hasil bahwa kualitas produk berpengaruh positif dan signifikan terhadap Word of mouth. Rambe, dkk (2017) menyimpulkan bahwa pelanggan melakukan Word of mouth setelah mendapatkan kualitas sesuai dengan harapan. Hal ini menandakan bahwa semakin baik kualitas pelayanan maka akan semakin tinggi pula berita dari mulut ke mulut (Word of mouth) yang terjadi.

Kepuasan konsumen bukan hanya dipengaruhi oleh kualitas produk, namun juga dapat dipengaruhi dengan merek produk tersebut. Semakin kuat citra merk di benak pelanggan maka semakin kuat pula rasa percaya diri pelanggan untuk tetap loyal atau setia, 
terhadap produk yang dibelinya sehingga hal tersebut dapat mengantar sebuah perusahaan untuk tetap mendapatkan keuntungan dari waktu ke waktu. Persaingan semakin meningkat diantara merek-merek yang beroperasi di pasar. Hanya produk yang memiliki brand image yang kuat yang tetap mampu bersaing dan mampu menguasai pasar (Damayanti, 2015). Hasil penelitian yang dilakukan oleh Dewi dkk. (2012), Evawati (2012), dkk. (2013), Pusparani dan Rastini (2014), Damayanti (2015) dan Pramudyo (2012) menemukan bahwa citra merek berpengaruh positif dan signifikan terhadap kepuasan konsumen.

Konsumen yang merasa puas atas terpenuhinya ekspektasi dan harapan konsumen akan merekomendasikan produk dengan citra merek yang baik (positive word of mouth) kepada orang lain karena ada perasaan bangga saat menggunakan produk tersebut. Komunikasi dari mulut ke mulut merupakan salah satu saluran komunikasi yang sering digunakan oleh perusahaan yang memproduksi baik barang maupun jasa karena komunikasi dari mulut ke mulut (word of mouth) dinilai sangat efektif dalam memperlancar proses pemasaran dan mampu memberikan keuntungan kepada perusahaan (Sari, 2014). Penelitian yang dilakukan oleh Wirawan (2012), Ismail and Spinelli (2012), Guna (2014), dan Satmoko, dkk (2015) menemukan hasil bahwa citra merek berpengaruh positif dan signifikan terhadap Word of mouth. Jadi, semakin baik citra merek, maka dapat meningkatkan intensitas konsumen untuk melakukan Word of mouth positif.

Berdasarkan masalah yang ditemukan terkait banyaknya pelanggan yang tidak puas pada pelayanan IndiHome, maka penelitian ini bertujuan untuk mengetahui dan menjelaskan pengaruh kualitas produk dan citra merek terhadap kepuasan pelanggan dan dampaknya terhadap komunikasi word of mouth pada pelanggan IndiHome di Kota Denpasar. Berdasarkan telaah dan kajian penelitian terdahulu, maka dapat disusun hipotesis sebagai berikut:

$\mathrm{H}_{1}$. Kualitas produk berpengaruh positif dan signifikan terhadap kepuasan Pelanggan IndiHome di Kota Denpasar.

$\mathrm{H}_{2}$ : Citra merek berpengaruh positif dan signifikan terhadap kepuasan pelanggan IndiHome di Kota Denpasar.

$\mathrm{H}_{3}$ : Kualitas Produk berpengaruh positif dan signifikan terhadap komunikasi word of mouth pelanggan IndiHome di Kota Denpasar.

$\mathrm{H}_{4}$ : Citra Merek berpengaruh positif dan signifikan terhadap komunikasi word of mouth pelanggan IndiHome di Kota Denpasar. 
$\mathrm{H}_{5}$. Kepuasan Pelanggan berpengaruh positif dan signifikan terhadap komunikasi word of mouth pelanggan IndiHome di Kota Denpasar.

Berdasarkan kajian penelitian terdahulu dan hipotesis yang sudah dirumuskan, maka model konseptual dalam penelitian ini adalah sebagai berikut:

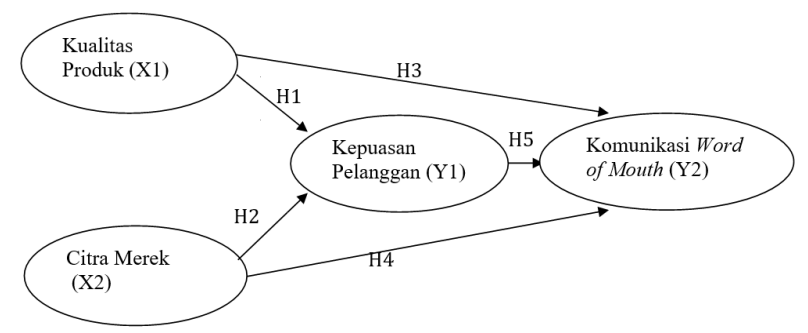

Gambar 2. Konsep Penelitian Sumber: kajian penelitian terdahulu

\section{METODE PENELITIAN}

Jenis penelitian ini menggunakan desain asosiatif, yaitu menguji pengaruh kualitas produk dan citra merek terhadap kepuasan pelanggan dan dampaknya pada komunikasi word of mouth. Penelitian ini di lakukan di PT. Telekomunikasi Indonesia, Tbk. Witel Kota Denpasar, lokasi ini dipilih karena terdapat beberapa masalah yang menarik untuk diteliti mengenai kualitas produk dan citra merek terhadap kepuasan dan dampaknya pada komunikasi word of mouth pelanggan IndiHome di PT. Tekelomunikasi
Indonesia, Tbk. Witel Kota Denpasar. Lokasi ini dipilih karena ditemukan banyaknya kasus komplain pelanggan terhadap layanan Indihome Triple Play selama bulan Maret 2018 hingga mencapai 51 pengaduan gangguan di Kota Denpasar. Berdasarkan hasil pra wawancara, responden menyatakan bahwa sering mengadukan komplainnya terkait layanan Indihome Triple Play di PT. Telkom Indonesia Tbk Witel Denpasar, namun tidak ada tindakan yang cepat untuk mengatasi masalah tersebut. Hal tersebut menunjukkan bahwa layanan Indihome Triple Play yang diberikan oleh PT. Telkom Indonesia Tbk Witel Denpasar belum maksimal.

Populasi dalam penelitian ini adalah seluruh pelanggan IndiHome di PT. Tekelomunikasi Indonesia, Tbk. Witel Kota Denpasar. Teknik pemilihan sampel menggunakan teknik purposive sampling, yaitu menggunakan kriteria bahwa Responden merupakan pengguna layanan Indihome minimal selama 1 Tahun, Bertempat tinggal di Kota Denpasar dan memiliki Jenjang pendidikan minimal SMA/SMK sederajat.

Indikator yang digunakan dalam penelitian ini sebanyak 13, maka jumlah 
sampel yang digunakan adalah 5-10 x 13 $=65-130$ sampel. Ukuran sampel yang digunakan dalam penelitian ini berjumlah 100 orang responden, karena 100 responden sudah termasuk dalam rentang 65 sampai 130 yang diestimasi. Pengumpulan data dalam penelitian ini selanjutnya dilakukan dengan menggunakan metode kuesioner, wawancara, dan observasi.

\section{HASIL DAN PEMBAHASAN}

Data penelitian diperoleh dari hasil kuesioner yang telah disebarkan kepada responden penelitian sejumlah 100 orang pelanggan IndiHome di Kota Denpasar. Karakteristik responden meliputi jenis kelamin, usia, dan tingkat pendidikan responden yang dapat dilihat pada Tabel 2.

Tabel 2 menunjukkan bahwa mayoritas responden yang berlanggan IndiHome dalam penelitian ini memiliki rentang usia 25 sampai 29 Tahun dengan jenjang pendidikan akhir Sarjana dan bekerja sebagai pegawai swasta. Data juga menunjukkan bahwa responden dalam penelitian ini adalah mayoritas yang sudah berlanggan IndiHome selama 3 sampai 6 Tahun.

Deskripsi jawaban responden menyajikan penilaian responden terhadap setiap butir-butir pertanyaan yang diajukan dalam kuesioner. Skala pengukuran yang dipergunakan mulai dari 1 sampai dengan 5. Semakin tinggi nilai ratarata yang diperoleh menunjukkan semakin baik tanggapan responden terhadap item maupun variabel tersebut.

Hasil analisis deksriptif sebagaimana disajikan pada Tabel 3 menunjukkan bahwa variabel kualitas produk secara keseluruhan memperoleh nilai rata-rata sebesar 3,48, yang berarti bahwa sebagian besar pelanggan IndiHome di Kota Denpasar menilai bahwa kualitas produk IndiHome yang dimiliki oleh Telkom sudah baik. Indikator yang memiliki nilai paling tinggi adalah indikator memiliki keunggulan produk. Hal tersebut disebabkan karena sebagian besar pelanggan menilai bahwa produk IndiHome memang memiliki kecepatan tinggi dibanding provider lainnya, sehingga nilai kualitas produk IndiHome di benak pelanggan termasuk dalam kriteria yang baik.

Skor rata-rata terendah pada variabel kualitas produk terdapat pada indikator kestabilan akses dengan nilai rata-rata sebesar 3,05. Hal tersebut menunjukkan cukup banyak pelanggan yang menilai bahwa akses internet dengan Produk IndiHome kurang stabil pada 
Tabel 2.

Karakteristik Pelanggan IndiHome di Kota Denpasar

\begin{tabular}{|c|c|c|c|c|}
\hline No & Karakteristik & Klasifikasi & $\begin{array}{l}\text { Jumlah } \\
\text { Responden } \\
\text { (orang) }\end{array}$ & $\begin{array}{l}\text { Persentase } \\
\text { Responden } \\
(\%)\end{array}$ \\
\hline \multirow{2}{*}{1} & \multirow{2}{*}{ Jenis Kelamin } & Laki-laki & 62 & 62 \\
\hline & & Perempuan & 38 & 38 \\
\hline \multirow{6}{*}{2} & \multirow{6}{*}{ Usia } & 15-19 Tahun & 6 & 6 \\
\hline & & 20-24 Tahun & 17 & 17 \\
\hline & & 25-29 Tahun & 22 & 22 \\
\hline & & 30-34 Tahun & 19 & 19 \\
\hline & & 35-39 Tahun & 20 & 20 \\
\hline & & $>40$ Tahun & 16 & 16 \\
\hline \multirow{4}{*}{3} & \multirow{4}{*}{$\begin{array}{l}\text { Jenjang } \\
\text { Pendidikan } \\
\text { Terakhir }\end{array}$} & SMA & 29 & 29 \\
\hline & & Diploma & 15 & 15 \\
\hline & & Sarjana & 37 & 37 \\
\hline & & Pascasarjana & 19 & 19 \\
\hline \multirow{6}{*}{4} & \multirow{6}{*}{ Pekerjaan } & Belum/Tidak Bekerja & 2 & 2 \\
\hline & & Pelajar/Mahasiswa & 22 & 22 \\
\hline & & Pegawai Swasta & 36 & 36 \\
\hline & & PNS & 10 & 10 \\
\hline & & Wirausaha & 27 & 27 \\
\hline & & Bekerja/Lainnya & 3 & 3 \\
\hline \multirow{3}{*}{5} & Lama & 1-3 Tahun & 32 & 32 \\
\hline & Menggunakan & 3-6 Tahun & 43 & 43 \\
\hline & Indihome & $>6$ Tahun & 25 & 25 \\
\hline
\end{tabular}

Sumber : Hasil pengolahan data primer, 2019

Tabel 3

Deskripsi Penilaian Responden Terhadap Variabel Kualitas produk

\begin{tabular}{lcccccccc}
\hline \multirow{2}{*}{\multicolumn{1}{c}{ Indikator }} & \multicolumn{4}{c}{$\begin{array}{c}\text { Frekuensi Jawaban } \\
\text { Responden }\end{array}$} & \multirow{2}{*}{$\begin{array}{c}\text { Rata - } \\
\text { Rata }\end{array}$} & Keterangan \\
\cline { 2 - 6 } & $\mathbf{1}$ & $\mathbf{2}$ & $\mathbf{3}$ & $\mathbf{4}$ & $\mathbf{5}$ & \\
\hline Kestabilan akses $\left(\mathrm{X}_{1.1}\right)$ & 6 & 32 & 25 & 25 & 12 & 3,05 & Cukup \\
\hline Memiliki keunggulan produk $\left(\mathrm{X}_{1.2}\right)$ & 2 & 12 & 20 & 34 & 32 & 3,82 & Baik \\
\hline Kualitas jaringan $\left(\mathrm{X}_{1.3}\right)$ & 1 & 15 & 30 & 32 & 22 & 3,59 & Baik \\
\hline \multicolumn{1}{c}{ Rata-rata Skor Variabel Kualitas produk } & & $\mathbf{3 , 4 8}$ & Baik \\
\hline \hline
\end{tabular}

Sumber: Data primer diolah, 2019

saat cuaca buruk. Oleh karena itu, dalam upaya

meningkatkan kualitas produk menjadi lebih

baik, maka PT, Telkom Witel, Tbk di Kota

Denpasar sebaiknya selalu mengevaluasi dan

memperbaiki jaringannya agar dapat tetap stabil memperoleh nilai rata-rata sebesar 3,74, 


\section{Tabel 4}

Deskripsi Penilaian Responden Terhadap Variabel Citra Merek

\begin{tabular}{lcccccccc}
\hline \multirow{2}{*}{ Indikator } & \multicolumn{5}{c}{$\begin{array}{c}\text { Frekuensi Jawaban } \\
\text { Responden }\end{array}$} & & \multirow{2}{*}{$\begin{array}{c}\text { Rata - } \\
\text { Rata }\end{array}$} & Keterangan \\
\cline { 2 - 6 } & $\mathbf{1}$ & $\mathbf{2}$ & $\mathbf{3}$ & $\mathbf{4}$ & $\mathbf{5}$ & \\
\hline $\begin{array}{l}\text { Merek yang muncul pertama } \\
\text { dalam benak / pikiran }\left(\mathrm{X}_{2.1}\right)\end{array}$ & 1 & 5 & 15 & 59 & 20 & 3,92 & Baik \\
\hline $\begin{array}{l}\text { Percaya bahwa perusahaan selama } \\
\text { ini baik }\left(\mathrm{X}_{2.2}\right)\end{array}$ & 3 & 4 & 21 & 36 & 36 & 3,98 & Baik \\
\hline $\begin{array}{l}\text { Mudah dihubungi }\left(\mathrm{X}_{2.3}\right) \\
\text { Rata-rata Skor Variabel Citra merek }\end{array}$ & 3 & 13 & 43 & 32 & 9 & 3,31 & Cukup \\
\hline
\end{tabular}

Sumber: Data primer diolah, 2019

yang berarti bahwa sebagian besar pelanggan

IndiHome di Kota Denpasar menilai bahwa citra merek IndiHome sudah baik. Indikator yang memiliki nilai paling tinggi adalah indikator percaya bahwa perusahaan selama ini baik. Hal tersebut disebabkan karena sebagian besar responden menilai bahwa PT. Tekelomunikasi Indonesia, Tbk. Witel Kota Denpasar merupakan perusahaan yang memiliki reputasi baik.

Skor rata-rata terendah pada variabel citra merek terdapat pada indikator mudah dihubungi dengan nilai rata-rata sebesar 3,05. Hal tersebut menunjukkan bahwa masih ada beberapa orang pelanggan yang merasa jika PT. Tekelomunikasi Indonesia, Tbk. Witel Kota Denpasar susah dihubungi saat menyampaikan keluhan mengenai layanan IndiHome. Oleh karena itu, dalam upaya meningkatkan citra merek perusahaan, maka PT. Tekelomunikasi
Indonesia, Tbk. Witel Kota Denpasar sebaiknya membuat program costomer service atau costomer care yang mampu melayani pelanggan secara optimal, agar pelanggan dapat dengan mudah menyampaikan keluhannya, sehingga PT. Tekelomunikasi Indonesia, Tbk. Witel Kota Denpasar dapat memperbaiki layanan terkait produk IndiHome menjadi lebih baik.

Hasil analisis deksriptif sebagaimana disajikan pada tabel 5 menunjukkan bahwa variabel kepuasan pelanggan secara keseluruhan memperoleh nilai rata-rata sebesar 3,76, yang berarti bahwa sebagian besar pelanggan IndiHome yang menjadi responden dalam penelitian ini memiliki kepuasan yang tinggi terhadap produk IndiHome. Indikator yang memiliki nilai paling tinggi adalah indikator kepuasan terhadap fasilitas. Hal tersebut disebabkan karena sebagian besar pelanggan 
Tabel 5

Deskripsi Penilaian Responden Terhadap Variabel Kepuasan pelanggan

\begin{tabular}{lcccccccc}
\hline \multirow{2}{*}{ Indikator } & \multicolumn{6}{c}{$\begin{array}{c}\text { Frekuensi Jawaban } \\
\text { Responden }\end{array}$} & $\begin{array}{c}\text { Rata } \\
\text {-Rata }\end{array}$ & Keterangan \\
\cline { 2 - 9 } & $\mathbf{1}$ & $\mathbf{2}$ & $\mathbf{3}$ & $\mathbf{4}$ & $\mathbf{5}$ & & \\
\hline Terpenuhinya harapan konsumen $\left(\mathrm{Y}_{1.1}\right)$ & 2 & 8 & 13 & 44 & 33 & 3,98 & Tinggi \\
\hline Perasaan puas menggunakan produk $\left(\mathrm{Y}_{1.2}\right)$ & 2 & 11 & 15 & 50 & 22 & 3,79 & Tinggi \\
\hline Kepuasan terhadap fasilitas $\left(\mathrm{Y}_{1.3}\right)$ & 4 & 8 & 13 & 24 & 51 & 4,10 & Tinggi \\
\hline Kepuasan terhadap pelayanan $\left(\mathrm{Y}_{1.4}\right)$ & 4 & 15 & 46 & 28 & 7 & 3,19 & Cukup \\
\hline \multicolumn{1}{c}{ Rata-rata Skor Variabel Kepuasan pelanggan } & & $\mathbf{3 , 7 6}$ & Tinggi \\
\hline
\end{tabular}

Sumber: Data primer diolah, 2019

IndiHome di Kota Denpasar puas dengan fasilitas produk IndiHome yang memiliki akses internet dengan kecepatan tinggi.

Skor rata-rata terendah pada variabel kepuasan pelanggan terdapat pada indikator kepuasan dengan pelayanan dengan nilai rata-rata sebesar 3,19. Hal tersebut menunjukkan bahwa pelanggan IndiHome di Kota Denpasar cukup banyak yang tidak puas dengan pelayanan yang diberikan IndiHome dari PT. Tekelomunikasi Indonesia, Tbk. Witel Kota Denpasar. Hasil survei dan wawancara dengan responden yang tidak puas terhadap pelayanan, menunjukkan bahwa seringkali pada saat mengadukan keluhan terkait gannguan fiber optik, internet yang melambat ataupun terkait koneksi internet yang terputus secara tiba-tiba tersebut tidak segera ditangani oleh pihak PT. Tekelomunikasi
Indonesia, Tbk. Witel Kota Denpasar, sehingga pelanggan menilai bahwa kualitas pelayanan perlu ditingkatkan. Oleh karena itu, dalam upaya meningkatkan kepuasan pelanggan menjadi lebih baik, maka PT. Tekelomunikasi Indonesia, Tbk. Witel Kota Denpasar sebaiknya segera dan cepat tanggap dalam mengatasi keluhankeluhan yang disampaikan oleh pelanggan, terutama terkait keluhan gannguan fiber optik, internet yang melambat ataupun terkait koneksi internet yang terputus secara tiba-tiba yang sering di komplain.

Hasil analisis deksriptif sebagaimana disajikan pada tabel 6 menunjukkan bahwa variabel komunikasi word of mouth secara keseluruhan memperoleh nilai rata-rata sebesar 3,68 , yang berarti bahwa sebagian pelanggan IndiHome di Kota Denpasar memiliki perilaku 
Tabel 6.

Deskripsi Penilaian Responden Pada Variabel Komunikasi word of mouth

\begin{tabular}{|c|c|c|c|c|c|c|c|}
\hline \multirow[t]{2}{*}{ Indikator } & \multicolumn{5}{|c|}{$\begin{array}{c}\text { Frekuensi Jawaban } \\
\text { Responden }\end{array}$} & \multirow{2}{*}{$\begin{array}{l}\text { Rata } \\
\text {-Rata }\end{array}$} & \multirow[t]{2}{*}{ Keterangan } \\
\hline & 1 & 2 & 3 & 4 & 5 & & \\
\hline $\begin{array}{l}\text { Menceritakan hal positif tentang } \\
\text { produk }\left(\mathrm{Y}_{2.1}\right)\end{array}$ & 0 & 8 & 32 & 41 & 19 & 3,71 & Tinggi \\
\hline $\begin{array}{l}\text { Merekomendasikan kepada orang } \\
\text { lain }\left(\mathrm{Y}_{2.2}\right)\end{array}$ & 2 & 4 & 20 & 44 & 30 & 3,96 & Tinggi \\
\hline Meyakinkan orang lain $\left(\mathrm{Y}_{2.3}\right)$ & 1 & 11 & 46 & 33 & 9 & 3,38 & Cukup \\
\hline \multicolumn{6}{|c|}{ Rata-rata Skor Variabel Komunikasi word of mouth } & 3,68 & Tinggi \\
\hline
\end{tabular}

Sumber: Data primer diolah, 2019

komunikasi word of mouth yang tinggi. Indikator

yang memiliki nilai paling tinggi adalah

indikator merekomendasikan kepada orang

lain. Hal tersebut disebabkan karena sebagian

besar pelanggan bersedia merekomendasikan

produk Telkom IndiHome kepada orang lain

karena produk IndiHome memang terbukti

memiliki kecepatan akses internet yang tinggi

dibandingkan provider lainnya.

Skor rata-rata terendah pada variabel komunikasi word of mouth terdapat pada indikator meyakinkan orang lain dengan nilai rata-rata sebesar 3,38. Hal ini menunjukkan bahwa sebagian besar pelanggan tidak mampu meyakinkan orang lain bahwa produk Telkom IndiHome memiliki akses internet yang stabil. Hal tersebut disebabkan karena seringnya terjadi gangguan koneksi putus atau melambat tiba-tiba yang dialami pelanggan. Jadi walaupun produk IndiHome mampu memberikan akses internet dengan kecepatan tinggi, tapi apabila sering mengalami koneksi putus dan melambat tiba-tiba, maka pelanggan tidak akan mampu meyakinkan orang lain bahwa produk Telkom IndiHome memiliki akses internet yang stabil. Oleh karena itu, dalam upaya meningkatkan komunikasi word of mouth pelanggan menjadi lebih baik, maka PT. Tekelomunikasi Indonesia, Tbk. Witel Kota Denpasar sebaiknya mencari penyebab akses internet pelanggan yang sering putus kemudian meningkatkan perbaikan teknis agar akses internet dapat digunakan secara stabil oleh pelanggan.

Pengujian data dalam penelitian ini menggunakan teknik analisis jalur (Path Analysis). Perhitungan koefisien path dilakukan dengan menggunakan software SPSS 18.0 for Windows, dan diperoleh hasil pada Tabel 7. Berdasarkan hasil analisis jalur substruktur 1 seperti yang disajikan pada Tabel 
Tabel 7

Hasil Uji Path Analysis (Struktur 1)

\begin{tabular}{|c|c|c|c|c|c|}
\hline \multirow{2}{*}{ Variabel } & \multicolumn{2}{|c|}{ Unstandardized Coefficients } & \multirow{2}{*}{$\begin{array}{c}\begin{array}{c}\text { Standardized } \\
\text { Coefficients }\end{array} \\
\text { Beta }\end{array}$} & \multirow{2}{*}{$\mathrm{t}$ hitung } & \multirow{2}{*}{ Sig. uji t } \\
\hline & B & Std. Error & & & \\
\hline (Constant) & 6,500 & 1,618 & & 4,017 & 0,000 \\
\hline Kualitas Produk & 0,270 & 0,117 & 0,218 & 2,297 & 0,024 \\
\hline Citra Merek & 0,512 & 0,135 & 0,360 & 3,795 & 0,000 \\
\hline
\end{tabular}

Sumber: Data primer diolah, 2019

\section{Tabel 8.}

Hasil Uji Path Analysis (Struktur 2)

\begin{tabular}{|c|c|c|c|c|c|}
\hline \multirow{2}{*}{ Variabel } & \multicolumn{2}{|c|}{$\begin{array}{c}\text { Unstandardized } \\
\text { Coefficients }\end{array}$} & \multirow{2}{*}{$\begin{array}{c}\text { Standardized } \\
\text { Coefficients }\end{array}$} & \multirow{2}{*}{$\mathrm{t}$ hitung } & \multirow{2}{*}{ Sig. uji t } \\
\hline & B & Std. Error & & & \\
\hline (Constant) & 3,213 & 0,958 & & 3,353 & 0,001 \\
\hline Kualitas Produk & 0,247 & 0,066 & 0,316 & 3,732 & 0,000 \\
\hline Citra Merek & 0,300 & 0,079 & 0,335 & 3,790 & 0,000 \\
\hline Kepuasan Pelanggan & 0,125 & 0,056 & 0,199 & 2,252 & 0,027 \\
\hline
\end{tabular}

Sumber: Data primer diolah, 2019

7, maka persamaan strukturnya adalah $\mathrm{Y}_{1}=$ nilai signifikansi uji $\mathrm{t}$ kurang dari 0,05 . Hal ini $0,218 \mathrm{X}_{1}+0,512 \mathrm{X}_{2}$ dengan model analisis menunjukkan bahwa seluruh variabel bebas sebagai berikut : yaitu kualitas produk dan citra merek memiliki

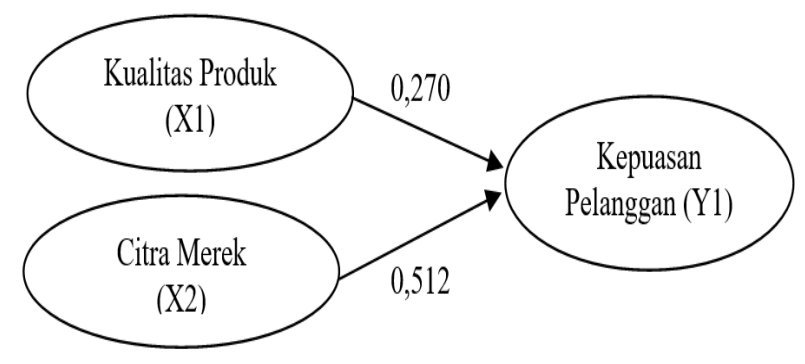

Gambar 3. Model Analisis Struktur 1

Sumber: Data diolah, 2019

Nilai koefisien regresi variabel kualitas produk dan citra merek bernilai positif dengan pengaruh positif yang signifikan terhadap variabel kepuasan pelanggan.

Berdasarkan hasil analisis jalur substruktur 2 seperti yang disajikan pada Tabel 8, maka persamaan strukturnya adalah $\mathrm{Y}_{2}=$ $0,316 \mathrm{X}_{1}+0,335 \mathrm{X}_{2}+0,199 \mathrm{Y}_{1}$ dengan model analisis sebagai berikut :

Nilai koefisien regresi masing-masing variabel bebas bernilai positif dengan nilai 


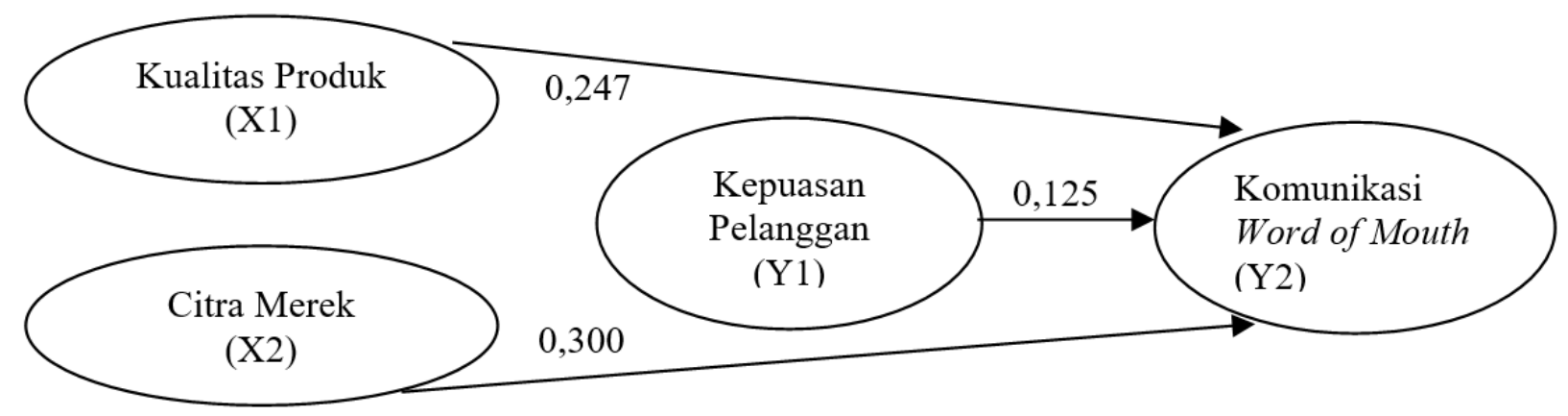

Gambar 4. Model Analisis Struktur 2

Sumber: Data diolah, 2019

signifikansi uji t kurang dari 0,050. Hal ini sebesar 21,4\% variasi kepuasan pelanggan menunjukkan bahwa semua variabel bebas dipengaruhi oleh variasi kualitas produk $\left(\mathrm{X}_{1}\right)$, yaitu kualitas produk $\left(\mathrm{X}_{1}\right)$, citra merek $\left(\mathrm{X}_{2}\right)$, dan dan citra merek $\left(\mathrm{X}_{2}\right)$, sedangkan sisanya sebesar kepuasan pelanggan $\left(\mathrm{Y}_{1}\right)$, memiliki pengaruh $78,6 \%$ dijelaskan oleh faktor lain yang tidak positif yang signifikan terhadap variabel dimasukkan ke dalam model. komunikasi word of mouth $\left(\mathrm{Y}_{2}\right)$.

Hasil uji koefisien determinasi dalam penelitian ini dapat dilihat dalam Tabel bebas terhadap variabel terikat yang ditunjukkan 9. Tabel 9 menunjukkan pada persamaan oleh nilai determinasi (Adjusted $R$ Square) struktur 1 (analisis jalur 1) besarnya pengaruh sebesar 0,406 mempunyai arti bahwa sebesar variabel bebas terhadap variabel terikat yang $40,6 \%$ variasi komunikasi word of mouth ditunjukkan oleh nilai determinasi (Adjusted $R$ dipengaruhi oleh variasi kualitas produk $\left(\mathrm{X}_{1}\right)$, Square) sebesar 0,214 mempunyai arti bahwa citra merek $\left(\mathrm{X}_{2}\right)$, dan kepuasan pelanggan $\left(\mathrm{Y}_{1}\right)$,

Tabel 9.

Hasil Koefisien Determinasi

\begin{tabular}{cccc}
\hline \hline Struktur & Persamaan & $\boldsymbol{R}$ Square & Adjusted R Square \\
\hline 1 & $\mathrm{Y}_{1}=0,218 \mathrm{X}_{1}+0,512 \mathrm{X}_{2}+\mathrm{e}_{1}$ & 0,230 & 0,214 \\
2 & $\mathrm{Y}_{2}=0,316 \mathrm{X}_{1}+0,335 \mathrm{X}_{2}+0,199 \mathrm{Y}_{1}+\mathrm{e}_{2}$ & 0,424 & 0,406 \\
\hline
\end{tabular}

Sumber: Data diolah, 2019 
sedangkan sisanya sebesar 59,4\% dijelaskan oleh faktor lain yang tidak dimasukkan ke dalam model.

Berdasarkan model substruktur 1 dan substruktur 2, maka dapat disusun model diagram jalur akhir. Sebelum menyusun model diagram jalur akhir, terlebih dahulu dihitung nilai standar eror sebagai berikut :

$$
\begin{aligned}
& \mathrm{Pe}_{\mathrm{i}}=\sqrt{1-\mathrm{R}_{\mathrm{i}}{ }^{2}} \\
& \mathrm{Pe}_{1}=\sqrt{1-{R_{1}}^{2}}=\sqrt{1-0,214}=0,886 \\
& \mathrm{Pe}_{2}=\sqrt{1-{R_{2}}^{2}}=\sqrt{1-0,406}=0,771
\end{aligned}
$$

Berdasarkan perhitungan pengaruh error (Pei), didapatkan hasil pengaruh error $\left(\mathrm{Pe}_{1}\right)$ sebesar 0,886 dan pengaruh error $\left(\mathrm{Pe}_{2}\right)$ sebesar 0,771. Hasil koefisien determinasi total adalah sebagai berikut :

Nilai determinasi total sebesar 0,534 mempunyai arti bahwa sebesar 53,4\% variasi

$$
\begin{aligned}
\mathrm{R}_{\mathrm{m}}{ }_{\mathrm{m}} & =1-\left(\mathrm{Pe}_{1}\right)^{2}\left(\mathrm{Pe}_{2}\right)^{2} \\
& =1-(0,886)^{2}(0,771)^{2} \\
& =1-(0,785)(0,594)=0,534
\end{aligned}
$$

komunikasi word of mouth dipengaruhi oleh variasi kualitas produk, citra merek, dan kepuasan pelanggan, sedangkan sisanya sebesar $46,6 \%$ djelaskan oleh faktor lain yang tidak dimasukkan ke dalam model.

Berdasarkan hasil analisis jalur 1 dan 2 yang tercantum dalam Tabel 7 dan 8, maka hasil koefisien jalur pada hipotesis penelitian ini dapat digambarkan pada Gambar 5.

Berdasarkan hasil analisis pengaruh Kualitas produk terhadap Kepuasan pelanggan diperoleh nilai Signifikasi sebesar 0,024 dengan nilai koefisien beta 0,218 . Nilai Signifikansi $0,024<0,050$ mengindikasikan bahwa $H_{1}$ diterima yaitu kualitas produk berpengaruh

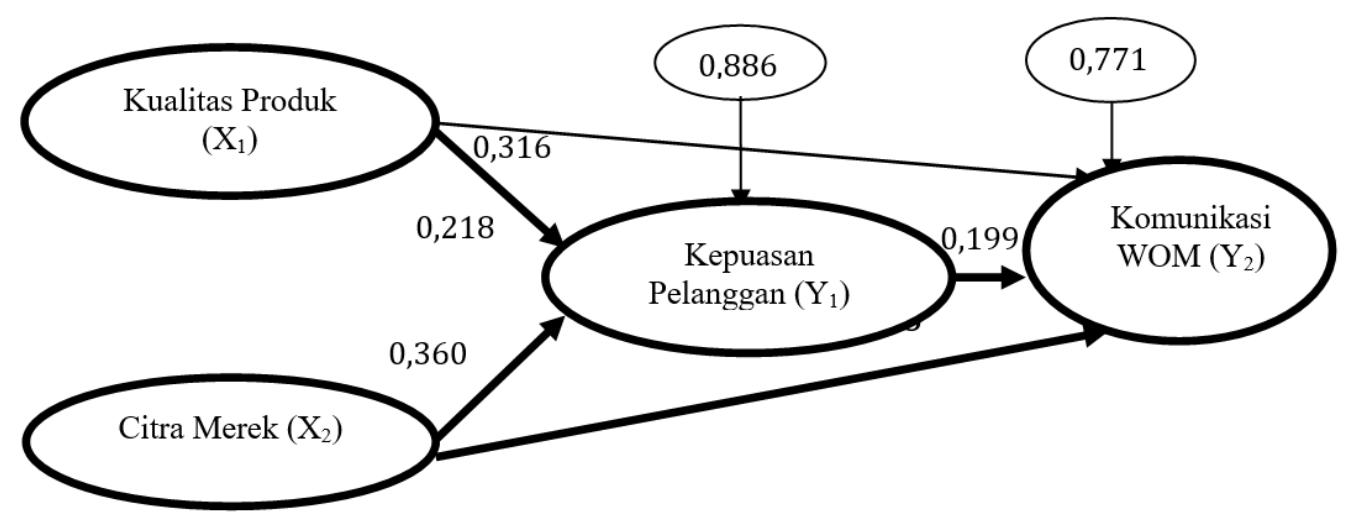

Gambar 5.

Model Diagram Jalur Akhir

Sumber: Data diolah, 2019 
positif dan signifikan terhadap kepuasan pelanggan IndiHome di Kota Denpasar. Hal ini berarti bahwa semakin baik kualitas produk IndiHome maka kepuasan pelanggan akan semakin meningkat. Begitu pula sebaliknya, semakin buruk kualitas produk IndiHome maka kepuasan pelanggan akan semakin menurun. Penelitian ini mendukung beberapa hasil penelitian sebelumnya dan konsisten dengan hasil penelitian yang dilakukan oleh Putra, dkk (2017), Puspita (2015), Wahyuni (2017), Wedarini (2013), Damayanti (2015) dan Setyawan (2015) menemukan bahwa kualitas produk berpengaruh positif dan signifikan terhadap kepuasan konsumen. Penelitian tersebut mengindikasikan kualitas produk yang baik akan mendasari peningkatan kepuasan konsumen. Hasil penelitian ini juga didukung oleh temuan Putra (2017), Chang dan Fong (2010) serta Natalia (2015) menemukan bahwa Terdapat pengaruh positif dan signifikan antara kualitas produk terhadap kepuasan pelanggan. Artinya semakin tinggi kualitas produk maka kepuasan pelanggan akan meningkat.

Berdasarkan hasil analisis pengaruh citra merek terhadap kepuasan pelanggan diperoleh nilai signifikansi sebesar 0,000 dengan nilai koefisien beta 0,360. Nilai Signifikansi 0,000< 0,05 mengindikasikan bahwa $\mathrm{H}_{2}$ diterima yaitu citra merek berpengaruh positif dan signifikan terhadap kepuasan pelanggan IndiHome di Kota Denpasar. Hal ini berarti bahwa semakin baik citra merek produk IndiHome di benak kosumen maka akan semakin meningkat kepuasan pelanggan terhadap produk IndiHome. Begitu pula sebaliknya, semakin buruk citra merek produk IndiHome di benak kosumen maka akan membuat kepuasan pelanggan semakin menurun. Penelitian ini mendukung beberapa hasil penelitian sebelumnya dan konsisten dengan hasil penelitian Dewi dkk. (2012), Evawati (2012), Pusparani dan Rastini (2014), Damayanti (2015) dan Pramudyo (2012) menemukan bahwa citra merek berpengaruh positif dan signifikan terhadap kepuasan konsumen. Hasil penelitian ini juga didukung oleh temuan Natalia (2015), Putri (2013), Chen (2010), dan Wismoyo (2017), yang menyatakan bahwa citra merek yang semakin tinggi di benak konsumen dapat meningkatkan kepuasan. Hal ini disebabkan karena jasa layanan Telkom IndiHome adalah provider yang terkenal, artinya semakin baik citra merek tersebut maka dapat memberikan nilai yang positif bagi IndiHome 
itu sendiri, karena semakin baik citra merek suatu produk dapat mempengaruhi kepuasan konsumen begitu juga sebaliknya apabila citra merek kurang baik maka dapat menurunkan kepuasan konsumen.

Berdasarkan hasil analisis pengaruh kualitas produk terhadap komunikasi word of mouth diperoleh nilai signifikasi sebesar 0,000 dengan nilai koefisien beta 0,316 . Nilai Signifikansi $0,000<0,05$ mengindikasikan bahwa $\mathrm{H}_{3}$ diterima yaitu kualitas produk berpengaruh positif dan signifikan terhadap Komunikasi word of mouth pada pelanggan IndiHome di Kota Denpasar. Hal ini berarti bahwa semakin baik kualitas produk IndiHome yang dirasakan oleh pelanggan maka akan semakin tinggi pula berita dari mulut ke mulut (Word of mouth) yang terjadi diantara pelanggan. Begitu pula sebaliknya, semakin buruk kualitas produk IndiHome yang dirasakan oleh pelanggan maka akan semakin rendah berita dari mulut ke mulut (Word of mouth) yang terjadi diantara pelanggan.

Penelitian ini mendukung beberapa hasil penelitian sebelumnya dan konsisten dengan hasil penelitian yang dilakukan oleh Rambe, dkk (2017), Zhang, et al. (2010), Pranastiti
(2012), Satmoko, dkk. (2015), dan Rambe, dkk (2017) memperoleh hasil bahwa kualitas produk berpengaruh positif dan signifikan terhadap Word of mouth. Hal ini berarti ketika produk yang dihasilkan perusahaan buruk maka yang akan terjadi adalah perilaku WOM yang negative kepada orang lain yang akan menggunakan produk yang sama. Sebaliknya jika produk yang dihasilkan perusahaan bagus maka yang akan terjadi adalah perilaku WOM yang positif, salah satunya dapat berupa rekomendasi dan dorongan kepada rekan untuk membeli produk yang sama juga. Sebelum konsumen melakukan komunikasi WOM, konsumen terlebih dahulu menganalisis kualitas produk tersebut, apakah sesuai dengan ekspektasi atau harapan mereka atau tidak. Apabila suatu produk memiliki kualitas sesuai ekspektasi konsumen bahkan melebihi, maka konsumen tersebut akan melakukan WOM yang positif kepada orang lain.

Berdasarkan hasil analisis pengaruh citra merek terhadap komunikasi word of mouth diperoleh nilai signifikansi sebesar 0,000 dengan nilai koefisien beta 0,335 . Nilai Signifikansi $0,000<0,05$ mengindikasikan bahwa $\mathrm{H}_{4}$ diterima yaitu citra merek berpengaruh positif 
dan signifikan terhadap Komunikasi word komunikasi dari dari mulut ke mulut atau word of mouth pada pelanggan IndiHome di Kota of mouth positif. Hal ini menandakan bahwa Denpasar. Hal ini berarti bahwa semakin baik citra merek produk IndiHome di benak kosumen maka intensitas konsumen untuk melakukan Word of mouth positif akan semakin meningkat. semakin baik citra merek maka akan semakin tinggi pula berita dari mulut ke mulut (Word of mouth) yang terjadi.

Berdasarkan hasil analisis pengaruh Begitu pula sebaliknya, semakin buruk citra merek produk IndiHome di benak kosumen Kepuasan pelanggan terhadap Komunikasi word of mouth diperoleh nilai signifikansi maka intensitas konsumen untuk melakukan sebesar 0,027 dengan nilai koefisien beta 0,199. Word of mouth positif akan semakin rendah. Nilai signifikansi 0,027<0,05 mengindikasikan Penelitian ini mendukung beberapa hasil bahwa $\mathrm{H}_{0}$ ditolak dan $\mathrm{H}_{5}$ diterima. Hasil ini penelitian sebelumnya dan konsisten dengan mempunyai arti bahwa Kepuasan pelanggan hasil penelitian Wirawan (2012), Ismail and Spinelli (2012), Guna (2014), dan Satmoko, dkk (2015) menemukan hasil bahwa citra merek berpengaruh positif dan signifikan terhadap Word of mouth. Hal ini berarti bahwa ekuitas merek dibentuk ketika konsumen familiar terhadap merek yang memiliki merek yang favorit,kuat dan unik yang akan tersimpan dalam ingatan konsumen. Citra merek yang positif akan membentuk persepsi konsumen yang positif juga, kemudian mendorong konsumen tersebut untuk merekomendasikan kepada orang lain. Hasil penelitian ini juga didukung oleh temuan Rambe, dkk. (2017) yang menyimpulkan bahwa citra merek yang positif akan membentuk suatu berpengaruh positif dan signifikan terhadap Komunikasi word of mouth pada pelanggan IndiHome di Kota Denpasar. Semakin tinggi tingkat kepuasan pelanggan maka akan berpengaruh pada semakin meningkatnya komunikasi word of mouth positif yang dilakukan oleh pelanggan IndiHome di Kota Denpasar. Begitu pula sebaliknya, semakin rendah tingkat kepuasan pelanggan pada produk IndiHome maka akan berpengaruh pada semakin berkurangnya komunikasi word of mouth positif yang dilakukan oleh pelanggan.

Penelitian ini konsisten dan sesuai dengan hasil penelitian yang dilakukan oleh Yassirly, dkk (2015), Erida (2009), Putri dan 
Suhariadi (2013) menemukan hasil bahwa pelanggan IndiHome di Kota Denpasar. kepuasan konsumen berpengaruh positif dan Saran yang dapat diberikan berdasarkan signifikan terhadap komunikasi word of mouth. hasil penelitian yaitu dalam upaya meningkatkan Hasil penelitian ini juga di dukung oleh temuan kualitas produk menjadi lebih baik, maka PT, Andreas (2012) yang mengatakan bahwa Telkom Witel, Tbk di Kota Denpasar sebaiknya kepuasan konsumen berpengaruh signifikan selalu mengevaluasi dan memperbaiki terhadap word of mouth, dimana semakin jaringannya agar dapat tetap stabil digunaka konsumen merasa puas maka semakin besar oleh pelanggan pada saat cuaca buruk. Dalam pula word of mouth yang disampaikan terhadap upaya meningkatkan citra merek perusahaan, perusahaan. maka PT. Tekelomunikasi Indonesia, Tbk. Witel Kota Denpasar sebaiknya membuat program

\section{SIMPULAN DAN SARAN}

Berdasarkan hasil penelitian dan pembahasan pada bab sebelumnya maka dapat bahwa : 1) kualitas produk berpengaruh positif dan signifikan terhadap Kepuasan pelanggan IndiHome di Kota Denpasar; 2) Citra merek berpengaruh positif dan signifikan terhadap kepuasan pelanggan IndiHome di Kota Denpasar; 3) Kualitas produk berpengaruh positif dan signifikan terhadap Komunikasi word of mouth pelanggan IndiHome di Kota Denpasar; 4) Citra merek berpengaruh positif dalam mengatasi keluhan-keluhan yang dan signifikan terhadap komunikasi word of disampaikan oleh pelanggan, terutama terkait mouth pelanggan IndiHome di Kota Denpasar; keluhan gannguan serat fiber optik, internet 5) Kepuasan pelanggan berpengaruh positif dan yang melambat ataupun terkait koneksi internet signifikan terhadap komunikasi word of mouth yang terputus secara tiba-tiba yang sering 
di komplain. Dalam upaya meningkatkan komunikasi word of mouth pelanggan menjadi lebih baik, maka PT. Tekelomunikasi Indonesia, Tbk. Witel Kota Denpasar sebaiknya mencari penyebab akses internet pelanggan yang sering putus kemudian meningkatkan perbaikan teknis agar akses internet dapat digunakan secara stabil oleh pelanggan, sehingga pelanggan akan bisa meyakinkan orang lain bahwa IndiHome memiliki akses internet yang stabil.

\section{REFERENSI}

Kepuasan Konsumen Terhadap Word of mouth Bengkel Kelud Motor Kediri. Jurnal Ekonomi Universitas Pembangunan Nasional "Veteran”. Vol. 1 No. 1,Hal: $1-10$

Asosiasi Penyelenggara Jasa Internet Indonesia. 2016. Penetrasi dan Perilaku Pengguna Internet Indonesia Hasil Survey 2016. www.apjii.or.id. Diunduh tanggal 1 November 2017.

Damayanti, Cintya. 2015. Pengaruh Kualitas Produk Dan Brand image Terhadap Loyalitas Pelanggan Dengan Kepuasan Konsumen Sebagai Variabel Intervening (Studi Pada Konsumen Produk "Supermi" di Kecamatan Genuk Semarang). Jurnal Ekonomi Universitas Negeri Semarang. Hal:1-9 https://ib. unnes.ac.id/22075/

Hakim, Muhammad Fauzul. 2015. Pengaruh Atribut Produk Terhadap Kepuasan Pelanggan (Studi Kasus pada Pelanggan Speedy PT. Telkom Yogyakarta). Jurnal Ekonomi Universitas Negeri Yogyakarta. Vol. 1 No. 1,Hal: 1-15

Ismail, Ahmed Rageh \& Spinelli, G. 2012. Effects of brand love, personality and image on word of mouth. Journal of
Fashion Marketing and Management. Vol. 16 No. 4, Hal: 386-398

Natalia, Selly. 2015. Pengaruh Citra Merek, Kualitas Produk Dan Kualitas Pelayanan Terhadap Loyalitas Pelanggan Melalui Kepuasan Pelanggan Pada Marcelio Speed Shop. Jurnal Manajemen Universitas Dian Nuswantoro Semarang. Vol. 01 No. 1,Hal: 1-19

Okezone Jurnalis. 2016. YLKI Terima Banyak Keluhan Konsumen soal Telkom IndiHome. https://techno.okezone.com/ $\mathrm{read} / 2016 / 06 / 15 / 207 / \quad 1416142 / \mathrm{ylki}$ terima-banyak-keluhan-konsumen-soaltelkomindihome. Diunduh tanggal 19 Oktober 2017

Pranastiti, Paula Dinar Widya. 2012. Hubungan Antara Kualitas Produk Dan Kepuasan Konsumen Dengan Word of mouth Communication Pada Mahasiswa Pengguna Blackberry Di Universitas Surabaya. Jurnal Ilmiah Mahasiswa Universitas Surabaya. Vol. 1, No. 1, http://journal.ubaya.ac.id/index.php/ jimus/article/view/45

Puspita, Baskara Try. 2015. Analisis FaktorFaktor Yang Mempengaruhi Kepuasan Pelanggan Produk Telkom Indihome Di Wilayah Kota Surakarta. Jurnal ekonomi Muhammadiyah Surakarta. Hal: 1-30 http://eprints.ums.ac.id/36143/1/02\%20 NASKAH\%20PUBLIKASI.pdf

Putra, Giardo Permadi, Zainul Arifin dan Sunarti. 2017. Pengaruh Kualitas Produk Terhadap Keputusan Pembelian Dan Dampaknya Terhadap Kepuasan Konsumen (Survei pada Mahasiswa Administrasi Bisnis Fakultas Ilmu Administrasi angkatan 2013 dan 2014 Universitas Brawijaya yang Melakukan Pembelian Paket Data Kampus). Jurnal Administrasi Bisnis (JAB), Vol. 48 No.1, Hal: 124-131

Putri, Nindhira Rossellini dan Fendy Suhariadi. 2013. Hubungan antara Kepuasan Pelanggan dengan Word of mouth pada Pelanggan Klinik Kecantikan London Beauty Centre. Jurnal Psikologi Industri dan Organisasi, Vol. 02 No. 1, Hal: 1-8

Rambe, Neni., Choiril Maksum, dan Moch Jasin. 2017. Pengaruh Pelayanan, Citra Merek Dan Harga Terhadap Pembelian Ulang 
Melalui Kepuasan Pelanggan Dan Word of mouth. Ekobisman-Jurnal Ekonomi Bisnis Manajemen. Hal:1-21 https:// nanopdf.com/download/pengaruhpelayanan-citra-merek-dan-harga_pdf

Sari, RR Dewi Asprina. 2014. Analisis Pengaruh Kualitas Produk, Kualitas Pelayanan, Dan Customer Value Terhadap Kepuasan Pelanggan Dan Dampaknya Terhadap Positive Word of mouth (Studi pada Pelanggan Telkom Speedy di Semarang). Jurnal Ekonomi dan Bisnis Universitas Diponegoro.Vol. 1, No 1, Hal:1-10.

Satmoko, Taufiq Dwi., Handojo Djoko, dan Ngatno. 2016. Pengaruh Kualitas Pelayanan Terhadap Word of mouth, Melalui Kepercayaan Dan Kepuasan Konsumen Sebagai Variabel Intervening Pada Star Clean Car Wash Semarang. Jurnal Ilmu Administrasi Bisnis. Vol. 5, No. 1. Hal:1-10.

Setyawan, Muammar Arif. 2015. Pengaruh Kualitas Layanan Dan Kualitas Produk Internet Banking Terhadap Kepuasan Nasabah Pada Bank Bri Pandanaran Semarang. Jurnal Ekonomi Universitas Negeri Semarang. Vol 1, No 1,Hal:1-25

Wahyuni, Desianty Fithri. 2017. Pengaruh Pelayanan dan Kualitas Produk Indihome Terhadap Kepuasan dan Loyalitas Pelanggan. Jurnal Manajemen Bisnis Telekomunikasi dan Informatika Universitas Telkom. Hal:1-8 htt ps:// aghina.staff.telkomuniversity.ac.id/ files/2017/03/Desianty-Fithri-Wahyuni1401144405-Metlit-09.pdf

Wedarini, Ni Made Sinta. 2013. Pengaruh Kualitas Produk Terhadap Kepuasan Dan Loyalitas Pelanggan Telkom Flexi. E-Jurnal Manajemen Fakultas Ekonomi Universitas Udayana. Vol. 2, No. 10, Hal: 495-512 https://ojs.unud. ac.id/index.php/Manajemen/article/ view/4776

Wirawan, I Wayan Gede \& Wibawa, IMA. 2012. Pengaruh Brand image dan Costumer Satisfaction terhadap Word of mouth di Krisna Oleh-Oleh Khas Bali. E-Jurnal Manajemen Fakultas Ekonomi Universitas Udayana. Vol. 1, No.1, Hal: 77-89

Wismoyo, Hery. 2017. Pengaruh Citra Merek,
Harga Dan Kualitas Pelayanan Terhadap Loyalitas Konsumen Dimediasi Kepuasan Konsumen Pada Jasa Layanan Telkom IndiHome di Kota Semarang. Jurnal Manajemen Universitas Dian Nuswantoro Semarang. Hal: 1-20 http://eprints.dinus.ac.id/22732/3/ jurnal_19816.pdf

Yassirly., Jüniwati dan Heriyadi. 2015. Pengaruh Kepuasan Terhadap Word of mouth (WOM) Pada Konsumen Penghuni Rumah Yang Ditawarkan Oleh PT. Putra Persada Khatulistiwa Pontianak. Jurnal Manajemen dan Bisnis. Vol.1,No.1,Hal:1.http://jurnal. untan.ac.id/index.php/jmdb/article/ view/7812

Zubair, Alief dan Trisyonowati. 2015. Pengaruh Kualitas Pelayanan Dan Kualitas Produk Terhadap Kepuasan Pelanggan First Media Surabaya. Jurnal Ilmu dan Riset Manajemen Vol. 4, No. 3, Hal: 1-19

Zhang, Jason Q., Georgiana Craciun and Dongwoo Shin. 2010. When does electronic word-of-mouth matter? A study of consumer product reviews. Journal of Business Research. Vol. 63, No. 12, pp: 1336-1341. 